Original Research Paper

\title{
Pemberian Pupuk Silikat dan Pupuk Kandang Terhadap Pertumbuhan, Kadar Brix, dan Hasil Tanaman Sorgum (Sorghum bicolor (L.) Moench)
}

\author{
Dita Apliza1, Mansur Ma'shum², Suwardji ${ }^{* *}$, Verina Januati Wargadalam ${ }^{3}$ \\ ${ }^{1}$ Program Studi Agroekoteknologi, Fakultas Pertanian Universitas Mataram, Indonesia \\ ${ }^{2}$ Program Studi Ilmu Tanah, Fakultas Pertanian Universitas Mataram, Indonesia \\ ${ }^{3}$ Pusat Penelitian dan Pengembangan Teknologi Ketenagalistrikan, Energi Baru dan Terbarukan, dan Konservasi Energi \\ (P3TKEBTKE) Kementrian ESDM, Jakarta, Indonesia
}

DOI: $10.29303 /$ jppipa.v6i1.229

Citation: Apliza, D., Ma'shum, M, Suwardji, Wargadalam, V. J. 2020. Pemberian Pupuk Silikat dan Pupuk Kandang terhadap Pertumbuhan, Kadar Brix, dan Hasil Tanaman Sorgum (Sorghum bicolor (L.) Moench). Jurnal Penelitian Pendidikan IPA (JPPIPA). 6(1). pp.16-24

\section{Article history}

Received: January $9^{\text {th }} 2019$

Revised: September $16^{\text {th }} 2019$

Accepted: October $18^{\text {th }} 2019$

*Suwardji: Program Studi Ilmu

Tanah, Fakultas Pertanian

Universitas Mataram,

Indonesia;

Email: suwardji@unram.ac.id
Abstract: Research on the application of silicate fertilizer and manure to growth, brix level, and yield of sorghum (Sorghum bicolor (L.) Moench) was investigated to find ways to increase sorghum productivity in the dry land. The research method used was an experimental method that was set in a randomized block design consisting of 9 treatments namely control (Si0P0), without silicate and manure, 5 tones/ha (Si0P5), without silicate and manure 10 tones/ha (Si0P10), silicate $100 \mathrm{~kg} / \mathrm{ha}$ and without manure (Si100P0), silicate $100 \mathrm{~kg} / \mathrm{ha}$ and manure 5 tones/ha (Si100P5), silicate $100 \mathrm{~kg} / \mathrm{ha}$ and manure 10 tones/ha (Si100P10), silicate $200 \mathrm{~kg} / \mathrm{ha}$ and without manure (Si200P0), silicate $200 \mathrm{~kg} / \mathrm{ha}$ and manure 5 tones/ha (Si200P5), and silicate $200 \mathrm{~kg} / \mathrm{ha}$ and manure 10 tones/ha (Si200P10). Each treatment was replicated 3 times and the size of the plot was $6 \times 6 \mathrm{~m} 2$. The results indicated that the application of silicate fertilizer and manure could significantly increase yield and brix levels. Application of silicate fertilizer of $200 \mathrm{~kg} / \mathrm{ha}$ and manure 5 tonnes/ha gave higher results for the production of sorghum was $6056 \mathrm{~kg} / \mathrm{ha}$. However, the growth of sorghum was not affected significantly to the growth of sorghum plants.

Keywords: Silicate Fertilizer (Si); Manure; Sorghum Plant.

Abstrak: Penelitian tentang pemberian pupuk silikat dan pupuk kandang terhadap pertumbuhan, kadar brix, dan hasil tanaman Sorgum (Sorghum bicolor (L.) Moench) dimaksudkan untuk mencari cara meningkatkan produktivitas sorgum di lahan kering. Metode penelitian yang digunakan adalah metode eksperimental, dengan menggunakan rancangan acak kelompok yang terdiri atas 9 perlakuan yaitu kontrol (SiOP0), tanpa silikat dan pupuk kandang 5 ton/ha (SiOP5), tanpa silikat dan pupuk kandang 10 ton/ha (SiOP10), silikat 100 $\mathrm{kg} / \mathrm{ha}$ dan tanpa pupuk kandang (Si100P0), silikat $100 \mathrm{~kg} / \mathrm{ha}$ dan pupuk kandang 5 ton/ha (Si100P5), silikat $100 \mathrm{~kg} / \mathrm{ha}$ dan pupuk kandang 10 ton/ha (Si100P10), silikat $200 \mathrm{~kg} / \mathrm{ha}$ dan tanpa pupuk kandang (Si200P0), silikat $200 \mathrm{~kg} / \mathrm{ha}$ dan pupuk pandang 5 ton/ha (Si200P5), dan silikat $200 \mathrm{~kg} / \mathrm{ha}$ dan pupuk kandang $10 \mathrm{ton} / \mathrm{ha}$ (Si200P10), perlakuan di ulang 3 kali dengan ukuran petak $6 \times 6 \mathrm{~m}^{2}$. Hasil penelitian menunjukan bahwa pemberian pupuk silikat dan pupuk kandang dapat meningkatkan hasil produksi dan kadar brix secara nyata. Pemupukan silikat $200 \mathrm{~kg} /$ hadan Pupuk Kandang 5 ton/ha memberikan hasil yang lebih baik terhadap produksi tanaman sorgum sebesar $6056 \mathrm{~kg} / \mathrm{ha}$. Namun pemupukan silikat dan pupuk kandang tidak berpengaruh nyata terhadap pertumbuhan tanaman sorgum.

Kata kunci: Pupuk Silikat (Si); Pupuk Kandang; Tanaman Sorgum 


\section{Pendahuluan}

Sorgum merupakan salah satu tanaman pangan yang tahan terhadap kondisi kekeringan dibandingkan tanaman pangan lainnya dan berpotensi untuk dikembangkan di Indonesia sebagai sumber pangan alternatif, sebagai sumber bahan baku energi baru dan terbarukan dan limbahnya dapat menjadi suber pakan ternak yang potensial (Diansyah, 2017). Keunggulan tanaman sorgum yang penting dari aspek budidaya tanaman adalah daya adaptasinya yang luas terhadap kondisi lahan suboptimal seperti lahan masam dan lahan kering (Toure et al., 2004; Suwardji et al, 2007). Dengan Potensi lahan kering yang dimiliki oleh Provinsi NTB yang sangat besar mencapai 1,84 juta hektar (Suwardji et al. 2003), peluang pengembangan sorgum sebagai sumber pangan, bahan baku etanol dan sumber pakan ternak di NTB sangatlah besar.

Tanaman sorgum khususnya sorgum manis yang batangnya mengandung nira dengan kadar lignoselulosa dan sakarida dan dapat menghasilkan fermentasi gula antara 6,510,1 ton/ha sangat sesuai dan dapat dimanfaatkan sebagai bahan baku hijauan pakan ternak yang bermutu, sebagai bahan baku bioetanol dan dapat menghasilkan pangan (Ratnavathi et al., 2010). Pengembangan tanaman sorgum di Indonesia masih tergolong tanaman pangan yang masih kurang mendapat perhatian dengan produktivitas yang masih sangat rendah sebesar 1 sampai 3.5 ton/ha (Galuh, 2012; Sutrisna, 2012) dibandingkan dengan produksi sorgum internasional yang mencapai 7-9 ton/ha. Pusat Riset Unggulan Pertanian Yang Tahan Terhadap Perubahan Iklim Universitas Mataram (CoE-CLEAR) sejak 2014 telah melakukan penelitian secara berkesinambungan tentang potensi dan kendala pengembangan sorgum manis di lahan kering Pulau Lombok (Diansyah, 2017; Hirjani et al 2015). Hasil penelitian Diansyah (2017) menunjukkan bahwa bahan pembenah tanah biochar dan pupuk kandang mampu meningkatkan produksi sorgum mencapai $>17 \%$. Selanjutnya hasil penelitian Hirjani dan Suwardji (2015), tentang pengaruh pemupukan NP dan $\mathrm{K}$ terhadap pertumbuhan, hasil dan kadar $\mathrm{N}$ tanaman sorgum, menunjukkan bahwa pemupukan NP dan K mampu meningkatkan pertumbuhan dan hasil sorgum lebih dari $27 \%$ dengan hasil tertinggi diperoleh 3,9 ton/ha.

Hasil analisis efisiensi penggunaan air (WUE) menunjukkan penambahan biochar dapat meningkatkan hasil biji tanaman $8-12 \mathrm{~kg} / \mathrm{mm} / \mathrm{ha}$ air yang diberikan per satu hektar lahan baik yang ditemukan Diansyah (2017) maupun hasil penelitian Hirjani dan Suwardji (2015) diperoleh angka yang relatif masih rendah $9-11 \mathrm{~kg} / \mathrm{mm} / \mathrm{ha}$. Hasil besarnya WUE dari kedua penelitian ini masih tergolong rendah. Hal ini menunjukkan bahwa masih ada faktor lain yang menjadi faktor pembatas pertumbuhan dan produksi sorgum di lahan kering di Kabupaten Lombok Utara sehingga efisiensi penggunaan air masih relatif rendah dibandingkan dengan WUE tanaman sorgum di berbagai negara USA, Australia dan India $20-22 \mathrm{~kg} / \mathrm{mm}$ air/Ha (Motagally, 2010).

Selanjutnya selain NPK, unsur hara silikat (Si) merupakan salah satu unsur hara mikro yang cukup banyak dibutuhkan oleh tanaman sereal dan dapat mencapai 5-11\% dalam kadar brangkasan kering. Silikat (Si) merupakan salah satu unsur hara yang dibutuhkan tanaman golongan gramineae seperti tanaman padi, tebu, jagung dan sorgum yang bersifat akumulator silikat. Silikat dapat menekan aktivitas enzim invertase dalam tebu, sehingga produksi sukrosa meningkat. Pengurangan aktivitas enzim fosfatase menyebabkan peningkatan penyediaan energi yang tinggi yang dibutuhkan untuk pertumbuhan tanaman tebu dan sorgum manis dan produksi gula yang optimal (Makarim, 2007). Silikat juga dapat mengurangi pengaruh kekeringan, memperkuat jaringan epidermis, mengurangi kekurangan air, dan menghambat infeksi jamur (Makarim, 2007).

Permasalahan kersuburan tanah entisol di lahan kering Kabupaten Lombok Utara (KLU) yang didomonasi tanah dengan tektur kasar (loamy sand) yang mempunyai kendala kesuburan fisik dan kimia (Tabel 1). Hal ini menjadi kendala utama dalam produksi pertanian lahan kering di daerah ini. Salah satu upaya yang dilakukan untuk meningkatkan kesuburan tanah adalah dengan melakukan modifikasi daerah perakaran melalui penambahan bahan pembenah tanah seperti pupuk kandang yang mampu meningkatkan kesuburan tanah. Pupuk kandang adalah salah satu pupuk organik yang memiliki kandungan hara lengkap yang dapat mendukung kesuburan tanah dan pertumbuhan mikroorganisme dalam tanah. Pupuk kandang dapat menyediakan unsur hara makro dan unsur mikro (Mayadewi, 2007; Nasahi, 2010). Oleh karena, itu pemberian bahan organik melalui berbagai sumber yang tersedia secara lokal menjadi alternatif penting untuk mengatasi permasalahan rendahnya produksi sorgum di wilayah ini.

Berdasarkan uraian di atas maka sangatlah penting untuk mengetahui Pengaruh Pemberian Pupuk Silikat (Si) dan Pupuk Kandang terhadap Pertumbuhan, Kadar Brix, dan Hasil Tanaman Sorgum (Sorghum bicolor (L.) Moench) di tanah Entisol Akar Akar Kabupaten Lombok Utara.

\section{Metode}

Penelitian ini menggunakan metode eksperimental yang dilaksanakan di lapangan. Percobaan dilaksanakan di Lahan Percobaan (Teaching Farm) Jurusan Ilmu Tanah Fakultas Pertanian Universitas Mataram di Desa Akar-Akar, Kecamatan Bayan Kabupaten Lombok Utara. Analisis Pupuk Kandang dilakukan di Laboratorium Analitik Universitas Mataram. Penelitian ini dilaksakan dari bulan Maret sampai bulan Juli 2018. 


\section{Bahan dan Alat Penelitian}

Alat-alat yang digunakan dalam penelitian ini adalah alat tulis-menulis, papan penanda petak, papan penanda tanaman sampel, penggaris, meteran, plastik sampel, tali raffia, ember, cangkul, timbangan, refractometer brik,tensometer, alat-alat untuk analisis bahan organik di Laboratorium, dan kamera.Bahan-bahan yang digunakan dalam penelitian ini adalah pupuk silikat (Si) Agrosil Korea, pupuk kandang, benih sorgum varietas Samurai 1 dan bahan-bahan kimia yang digunakan dalam analisis bahan organik di Laboratorium Analitik Universitas Mataram.

\section{Rancangan Percobaan}

Rancangan percobaan yang digunakan dalam penelitian ini adalah Randommized Blok Design (RCBD) yang terdiri atas 9 perlakuan yaitu: $\mathrm{Si}_{0} \mathrm{P}_{0}, \mathrm{Si}_{0} \mathrm{P}_{5}, \mathrm{Si}_{0} \mathrm{P}_{10}, \mathrm{Si}_{100} \mathrm{P}_{0}$, $\mathrm{Si}_{100} \mathrm{P}_{5}, \mathrm{Si}_{100} \mathrm{P}_{10}, \mathrm{Si}_{200} \mathrm{P}_{0}, \mathrm{Si}_{200} \mathrm{P}_{5}, \mathrm{Si}_{200} \mathrm{P}_{10}$ di ulang 3 kali sehingga didapat 27 petak percobaan dengan luas masing masing petak $6 \times 6 \mathrm{M}^{2}$. Kombinasi perlakuan tersebut adalah sebagai berikut:

SiOP0 : Kontrol

Si0P5: Tanpa pupuk silikat dan pupuk kandang 5 ton/ha

Si0P10: Tanpa pupuk silikat dan pupuk kandang 10 ton/ha

Si100P0: Pupuk silikat $100 \mathrm{~kg} / \mathrm{ha}$ dan tanpa pupuk kandang

Si100P5: Pupuk silikat $100 \mathrm{~kg} / \mathrm{ha}$ dan pupuk kandang 5 ton/ha

Si100P10: Pupuk silikat $100 \mathrm{~kg} / \mathrm{ha}$ dan Pupuk kandang 10 ton/ha

Si200P0: Pupuk silikat $200 \mathrm{~kg} / \mathrm{ha}$ dan tanpa pupuk kandang

Si200P5: Pupuk silikat $200 \mathrm{~kg} / \mathrm{ha}$ dan pupuk kandang 5 ton/ha

Si200P10: Pupuk silikat $200 \mathrm{~kg} / \mathrm{ha}$ dan pupuk kandang 10 ton/ha

\section{Pelaksanaan Percobaan dan dosis}

\section{Pupuk Silikat (Si) dan Pupuk Kandang}

Pupuk silikat Agrosil dengan dosis 0, 100 dan 200 $\mathrm{kg}$ Agrosil $/ \mathrm{Ha}$ atau setara dengan $0 \mathrm{~kg} /$ petak, $0,36 \mathrm{~kg} /$ petak dan $0,72 \mathrm{~kg} /$ petak. Pupuk kandang yang digunakan adalah pupuk kandang yang diperoleh dari kotoran ternak sapi yang telah difermentasi. Dosis pupuk kandang 5 ton/ha dan 10 ton/ha atau setara dengan $18 \mathrm{~kg} /$ petak dan $36 \mathrm{~kg} /$ petak.

\section{Pengolahan Tanah, Pembersihan Petak Percobaan dan Pemupukan Silika dan Pupuk Kandang}

Pengolahan tanah dilakukan dengan membersihkan areal dari gulma dan sampah. Kemudian tanah diolah dengan cara mencangkul kemudian dibuat plot-plotnya dengan ukuran $6 \mathrm{~m}$ x $6 \mathrm{~m}$ sebanyak 27 petak dengan 3 blok, jarak antar petak kurang lebih $50 \mathrm{~cm}$ dan jarak antar blok 65 $\mathrm{cm}$. Pupuk silikat dan pupuk kandang dicampur dengan permukaan tanah sedalam $10 \mathrm{~cm}$ dengan menggunakan cangkul sesuai dengan dosis yang telah ditetapkan untuk setiap plotnya sebagai pupuk dasar. Kemudian seluruh plot diairi dengan air irigasi dengan sistem pancar (sprinkle) mencapai kapasitas lapangan. Plot plot yang telah diairi kemudian diinkubasi selama dua hari.

\section{Penanaman}

Petakan yang telah siap ditanami dibuat lubang tanam dengan cara ditugal menggunakan jarak tanam $70 \mathrm{~cm}$ x $20 \mathrm{~cm}$. Setiap lubang tanam ditanami 2-3 benih sorgum, lubang tersebut ditutup kembali dengan tanah. Setelah tanam dilakukan pengairan sampai kapasistas lapangan menggunakan sistem irigasi pancar, pengukuran kapasistas lapangan menggunakan tensiometer sesuai Tabel 1.

\section{Pemeliharaan}

Pemeliharaan yang dilakukan meliputi penyiraman, penyiangangulma, pembumbunan, pengendalian HPT. Pada awal tanaman penyiraman dilakukan setiap dua hari, dan setelah tanaman tumbuh dilakukan penyiraman setiap 3 hari sekali sampai sampai umur 20 hari untuk menjamin tanaman tumbuh dengan baik dan tersedia lengas tanah yang memadai untuk perkembangan awal tanaman. Setelah tanaman tumbuh dengan baik pengairan dilakukan sesuai dengan kebutuhan tanaman/lengas tanah telah mencapai batas kritis bawah (Tabel 1) dilakukan1 kali seminggu. Penyiangan gulma dilakukan dengan pencabutan secara manual sesuai dengan pertumbuhan gulma hingga 4 MST (Diansyah, 2017) dan pada saat yang sama dilakukan pembubunan dilakukan dengan cara menggemburkan tanah di sekitar batang tanaman, kemudian menimbunkan tanah pada pangkal batang untuk merangsang pertumbuhan akar dan memperkokoh tanaman agar tidak mudah rebah jika terkena angin. Pengendalian hama dan penyakit tanaman dilakukan dengan cara kimiawi apabila ditemukan gejala serangan hama dan penyakit, pada saat penelitian ini tidak ditemukan hama dan penyakit sehingga tidak dilakukan penyemprotan dengan pestisida.

\section{Panen}

Pemanenan sorgum dilakukan pada saat sorgum mulai sudah cukup tua bijinya bernas, keras dan biji berwarna kuning. Panen dengan kriteria tersebut dilakukan pada umur 124 HST.

\section{Parameter Tanaman \\ Tinggi Tanaman $(\mathrm{cm})$}

Pengamatan tinggi dilakukan dengan cara mengukur tinggi tanaman dari pangkal batang di atas permukaan tanah sampai ujung titik tumbuh menggunakan meteran. Pengamatan dilakukan pada tanaman sampel yang telah ditandai ketika berumur 14, 28, 42, 56, 70, 84, 98 Hari Setelah Tanam (HST).

\section{Berat Berangkasan Basah dan Kering Batang (kg/ha)}

Berat berangkasan basah batang sorgum dilakukan dengan cara menimbang bagian atas tanaman dari tanah 
dengan menggunakan timbangan digital. Berat berangkasan kering batang sorghum dilakukan dengan menimbang bagian batang sorgum yang telah dikering anginkan selama empat minggu di dalam oven dengan suhu $60^{\circ} \mathrm{C}$ sampai didapatkan nilai berat yang konstan menggunakan timbangan digital dengan ketelitan $0,1 \mathrm{~g}$.

\section{Pengukuran Kadar Brix}

Pengukuran kadar brix dilakukan mulai dari fase vegetatif maksimum yaitu saat tanaman berumur 77 Hari Setelah Tanam (HST) dengan interval waktu 7 hari dan pada saat panen dengan menggunakan portable refractometer brik di lapangan dengan cara memotong bagian tanaman sorgum, dipisahkan daun dan bunga sorghum, tanaman sorghum di bagi menjadi tiga bagian yaitu bagian pucuk, tengah, dan bawah pada batang sorgum, untuk mendapatkan data rata-rata kadar brix pertanaman.

\section{Berat 1000 Butir Biji dan Berat Biji perplot (kg/ha)}

Berat 1000 butir biji sorgum dilakukan dengan cara menghitung 1000 butir biji sorgum dan menimbang biji yang sudah dipanen dan di hitung. Berat biji perplot diperoleh dengan menimbang seluruh berat biji perplot.

\section{Hasil dan Pembahasan}

\section{Karakteristik Sifat Tanah dan Pupuk Kandang Yang Digunkan Untuk Penelitian}

Hasil analisis beberapa sifat fisik dan kimia tanah dan pupuk kandang yang digunakan dalam percobaan ini disajikan pada Tabel 1 .

Tabel 1. Hasil Analisis Beberapa Sifat Fisik dan Kimia Tanah Yang Digunakan Dalam Penelitian

\begin{tabular}{lll}
\hline Sifat sifat Tanah & Nilai & Katagori \\
\hline $\mathrm{pH}\left(\mathrm{H}_{2} \mathrm{O}\right)$ & 6.28 & Netral \\
$\mathrm{N}$ Total $(\%)$ & 0.011 & Rendah \\
P Potensial $(\mathrm{mg} / 100)$ & 5.12 & Rendah \\
K Potensial $(\mathrm{mg} / 100)$ & 77.14 & Tinggi \\
Kation-dd & & \\
$\mathrm{K}(\mathrm{me} \%)$ & 0.18 & Rendah \\
$\mathrm{Na}(\%)$ & 0.10 & Rendah \\
$\mathrm{Ca}(\mathrm{me} \%)$ & 0.06 & Sangat rendah \\
$\mathrm{Mg}(\mathrm{me} \%)$ & 0.04 & Sangat rendah \\
$\mathrm{C} \mathrm{Organik}(\%)$ & 1.11 & Sangat rendah \\
Tekstur & & \\
Pasir $(\%)$ & 76 & \\
Debu $(\%)$ & 22 & \\
Klei $(\%)$ & 2 & \\
Kelas tekstur & Pasir Bergelung $($ loamy sand $)$ \\
$\mathrm{BV}$ & & $1.226 \mathrm{~g} / \mathrm{cm}^{3}$ \\
KPK (me/100 gr) & 12.6 & Rendah \\
P Olsen (ppm) & 18.20 & Rendah \\
Titik jenuh/pF=0 & $32 \%$ & Pembacaan \\
& & dengan \\
Kapasitas lapang (field & $20 \%$ & tensiometer 0 \\
capacity) = pF 4.2 & & Pembacaan \\
& & dengan \\
\hline
\end{tabular}

\begin{tabular}{lll}
\hline Sifat sifat Tanah & Nilai & Katagori \\
\hline & & tensiometer 2.2 \\
\hline $\begin{array}{l}\text { Titik layu permanen } \\
\text { (permanent wilting point) }=\end{array}$ & $8 \%$ & $\begin{array}{l}\text { Pembacaan } \\
\text { pF 4,2 }\end{array}$ \\
dengan \\
tensiometer 2.56
\end{tabular}

Lengas tanah tersedia $(\%) \quad 12 \%$

C/N ratio Pupuk Kandang $\quad 14,42 \%$

\section{Sumber: $\quad$ Data tanah awal dianalisis oleh Suwardji dan SH. Waluyo (2016), Data pupuk kandang dianalisis di Laboratorium Analitik, Universitas Mataram 2018.}

Hasil analisis sifat tanah pada Tabel 1 menunjukkan bahwa kemasaman tanah atau $(\mathrm{pH})$ tanah dalam percobaan ini masuk pada katagori agak masam, sangat cocok untuk pertumbuhan tanaman sorgum. Pada umumnya tanaman sorgum dapat tumbuh di tanah pada dengan $\mathrm{pH}$ 6-7,5. Amujoyegbe, et al., (2007), menyatakan bahwa untuk mendapatkan hasil produksi tanaman yang baik dibutuhkan tanah yang memiliki $\mathrm{pH}$ yang netral. Sorgum dapat tumbuh dengan baik didataran rendah, dengan ketinggian antara 1$500 \mathrm{~m} \mathrm{dpl} \mathrm{(di} \mathrm{atas} \mathrm{permukaan} \mathrm{laut).Pada} \mathrm{ketinggian} \mathrm{lebih}$ dari $500 \mathrm{~m}$ dpl umur panen sorgum menjadi lebih panjang (Muui,C.W. et al, 2013).

Sorgum dapat tumbuh baik pada berbagai jenis tanah (Adisarwanto, 2002). Tanah pada lahan percobaan termasuk katagori sub ordo Typicpsament tanah Entisol dengan kelas tekstur pasir geluh (loamy sand). Tanah Entisol yang digunakan untuk lokasi percobaan memiliki kelas tekstur yang kasar dan mempunyai pori tanah makro yang besar sehingga mudah meloloskan air dibandingkan dengan tekstur tanah yang lebih halus. Tekstur tanah mempunyai kaitan yang erat dengan ketersediaan air tanah bagi tanaman. Ma'shum (2013), menyatakan bahwa lahan kering di Kabupaten Lombok Utara memiliki tanah yang berbahan induk batu apung. Kendala sifat fisik pada tanah berbahan induk batu apung terkait dengan lingkungan tanah yang mendukung pertumbuhan tanaman meliputi porositas tanah yang tinggi, kemampuan tanah untuk menahan air yang rendah, kecepatan meloloskan air tinggi, dan stabilitas agregat yang rendah (Ma'shum, 2013).

Kandungan nitrogen $(\mathrm{N})$ total pada tanah adalah $0,01 \%$ memiliki kategori yang rendah, kadar fosfor $(\mathrm{P})$ adalah 5,12 memiliki katagori yang rendah, dan kalium (K) adalah 77,14 (me \%) memiliki kategori yang tinggi. Kadar nitrogen dan fosfor termasuk rendah yang menunjukan bahwa lahan percobaan tersebut termasuk katagori lahan yang kurang subur. Kadar C-organik pada tanah adalah $1,11 \%$ yang memiliki katagori sangat rendah dan KPK pada tanah adalah 12,6 me/100g tanah yang memiliki kategori rendah. Kandungan C-organik dalam tanah sangat berpengaruh terhadap sifat fisik, kimia, dan biologi tanah. Semakin tinggi C-organik maka tanah tersebut semakin subur (Afriani, 2018). Sifat kimia yang dipengaruhioleh kadar C-organiktanah antara lain strukturtanah, konsistensi tanah dan sifat kesuburan tanah termasuk KPK tanah. Makin tinggi KPK tanah maka makin banyak kation yang 
dapat diikat oleh tanah tersebut dan ada pada keseimbangan yang dapat dipertukarkan dalam larutan tanah yang menjadi tersedia bagi tanaman.

Bahan organik tanah telah banyak dilaporkan dapat meningkatkan KPK tanah, mengikat unsur $\mathrm{N}$, $\mathrm{P}$, dan $\mathrm{S}$ dalam bentuk organik sehingga terhindar dari pencucian, yang pada keseimbangan koloidal tanah yang dapat melarutkan sejumlah unsur hara dan meningkatkan jumlah dan aktivitas mikroorganisme tanah (Hakim et al, 1986). Pupuk kandang yang digunakan pada penelitian ini adalah pupukkotoran sapiyang mempunyai nisbah $\mathrm{C} / \mathrm{N}$ ratio $<20$, yang berarti sudah merupakan pupuk kandang yang matang.Hasil analisis sifat kimia pupuk kandang menunjukan bahwa $\mathrm{C} / \mathrm{N}$ ratio sebesar 14.42. Dari data $\mathrm{C} / \mathrm{N}$ Ratio pupuk kandang yang digunakan untuk penelitian ini menunjukkan bahwa pupuk kandang sudah masuk dalam katarogi masak dan dapat digunakan secara langsung tanpa harus melakukan pengomposan terlebih dahulu sebagai bahan pembenah tanah dan sebagai cadangan sumber unsur hara untuk tanaman.

Rekapitulasi analisis sidik ragam pengaruh pupuk silikat dan pupuk kandang terhadap pertumbuhan, kadar brix dan hasil tanaman sorgum ditampilkan pada Tabel 2.

Tabel 2. Hasil Analisis Keragaman Pengaruh Pupuk Kandang dan Pupuk Silikat Terhadap Pertumbuhan, Kadar Brix, dan Hasil Produksi Tanaman Sorgum

\begin{tabular}{|c|c|c|}
\hline Parameter Pengamatan & Blok & Perlakuan \\
\hline \multicolumn{3}{|l|}{ Tinggi Tanaman $(\mathrm{cm})$} \\
\hline 14 HST & NS & NS \\
\hline $28 \mathrm{HST}$ & NS & NS \\
\hline $42 \mathrm{HST}$ & $\mathrm{S}$ & NS \\
\hline $56 \mathrm{HST}$ & NS & NS \\
\hline 70 HST & $\mathrm{S}$ & NS \\
\hline 84 HST & $\mathrm{S}$ & NS \\
\hline 98 HST & NS & NS \\
\hline \multicolumn{3}{|l|}{ Kadar Brix Batang } \\
\hline 77 HST & $\mathrm{S}$ & $\mathrm{S}$ \\
\hline $91 \mathrm{HST}$ & $\mathrm{S}$ & $\mathrm{S}$ \\
\hline $101 \mathrm{HST}$ & $\mathrm{S}$ & NS \\
\hline 107 HST & $\mathrm{S}$ & $\mathrm{S}$ \\
\hline $128 \mathrm{HST}$ & $\mathrm{S}$ & $\mathrm{S}$ \\
\hline $\begin{array}{l}\text { Berat Berangkasan Basah } \\
(\mathrm{kg} / \mathrm{ha})\end{array}$ & NS & NS \\
\hline $\begin{array}{l}\text { BeratBerangkasan Kering } \\
(\mathrm{kg} / \mathrm{ha})\end{array}$ & $\mathrm{S}$ & NS \\
\hline Berat 1000 Biji & NS & NS \\
\hline Produksi Biji (kg/ha) & NS & $\mathrm{S}$ \\
\hline
\end{tabular}

Keterangan: $\mathrm{S}=$ Signifikan, NS = Non Signifikan

Hasil analisis dalam Tabel 2 menunjukkan bahwa blok tidak berpengaruh secara nyataterhadap tinggi tanaman pada umur 14 HST, 28 HST, 56 HST, 98 HST, hasil produksi berat biji ( $\mathrm{kg} / \mathrm{ha})$, berat 1000 biji (g), dan berat berangkasan basah (kg/ha) akan tetapi, blok berpengaruh secara nyata terhadap tinggi tanaman pada umur 42 HST, 70 HST dan 84 HST, kadar brix batang pada semua umur, dan berat berangkasan kering (kg/ha). Sedangkan perlakuan pupuk silikat dan pupuk kandang tidak berpengaruh secara nyata terdahap tinggi tanaman pada semua umur, kadar brix umur 101 HST, berat berangkasan basah dan kering, berat 1000 biji. Selanjutnya perlakuan pupuk silikat dan pupuk kandang berpengaruh secara nyata terhadap kadar brix umur 77 HST, 91 HST, 107 HST, 128 HST, dan hasil produksi berat biji sorgum.

\section{Pertumbuhan dan Hasil Tanaman Sorgum Tinggi Tanaman}

Data Tabel 2 menunjukkan bahwa respon tinggi tanaman terhadap pemberian pupuk silikat dan pupuk kandang tidak beda nyata pada semua umur tanaman sorgum. Hal ini menunjukkan bahwa tanah yang digunakan untuk penelitian sudah memiliki kandungan silika tersedia dalam jumlah yang cukup memadai untuk pertumbuhan tanaman. Lebih jauh tidak responnya tinggi tanaman terhadap pemberian pupuk kandang, menunjukkan bahwa pada kondisi awal sifat dan karakteristik tanah yang ada di lahan kering Lombok Utara, karena proses mineralisasi bahan organik menjadi unsur hara yang diperlukan oleh tanaman sorgum terjadi dengan kecepatan yang sangat lambat, atau terjadi pada aras yang belum mampu meningkatkan pertumbuhan tanaman. Hasil penelitian Noor dan Ningsih (1998) menunjukkan bahwa pupuk kadang sapi memiliki kadar K 1,03\%, N 0,92\%, P $0,23 \%, \mathrm{Ca} 0,38 \%, \mathrm{Mg} 0,38 \%$. Nilai kadar hara pupuk kandang yang disampaikanoleh Noor dan Ningsih (1998) termasuk dalam katagori relatif rendah sehingga boleh jadi hasil mineralisasinya yang berjalan relatif lambat belum mampu menyediakan jumlah unsur hara yang mampu meningkatkan pertumbuhan tanaman yang berbeda nyata dibandingkan dengan perlakuan kontrol.

Selanjutnya, menurut Ma'shum (2013), pemupukan dengan bahan organik membutuhkan dosis yang cukup tinggi dan ketersediaan harahasil mineralaisasi pupuk organik terjadi relatif lambat. Hal hal yang disampaikan dalam rujukan pustaka tersebut di atas mungkin yang menyebabkan pemberian pupuk kandang tidak berpengaruh secara nyata terhadap tinggi tanaman.

Selanjutnya data juga menunjukkan bahwa pemupukan silika tidak berpengaruh secara nyata terhadaptinggi tanaman. Hal ini menunjukkan bahwa tanah di wilayah Kabupaten Lombok Utara yang memiliki bahan induk yang berasal dari batu apung yang kaya silikat boleh jadi telah menghasilkan ketersediaan unsur hara silika dalam jumlah yang memadai yang mampu mendukung pertumbuhan tanaman sorgum. Hasil penelitiaan ini sejalan dengan penelitian Puteri (2014), menyatakan pemberian pupuk silikat sampai $400 \mathrm{~kg} / \mathrm{ha}$ mengahasilkan pertumbuhan tanaman kedelai tidak berbeda nyata yang hal ini 
diduga karena kandungan $\mathrm{Si}$ pada tanah-tanah di daerah tropis sudah sangat tinggi sekitar $5-40 \% \mathrm{Si}$ sehingga pemberian pupuk silikat tidak berpengaruh terhadap petumbuhan tanaman kedelai.

\section{Produksi Biji (kg/ha) dan Berat 1000 biji (g)}

Pengaruh pupuk silikat (Si) dan pupuk kandang tidak berbeda nyata terhadap Berat Biji Perplot (kg/ha) dapat di lihat pada tabel 4 .

Tabel 3. Rerata Produksi Biji (kg/ha) dan Berat 1000 biji

\begin{tabular}{lll}
\hline Perlakuan & $\begin{array}{l}\text { Berat 1000 } \\
\text { Biji (gram) }\end{array}$ & $\begin{array}{l}\text { Hasil Produksi Berat } \\
\text { Biji (Kg/ha) }\end{array}$ \\
\hline SI100P0 & 25.67 & $5115 \mathrm{ab}$ \\
SI200P5 & $26.00^{*}$ & $6056 \mathrm{a}$ \\
SI0P10 & 24.33 & $4715 \mathrm{ab}$ \\
SI200P10 & 25.33 & $5147 \mathrm{ab}$ \\
SI100P10 & 21.67 & $5063 \mathrm{ab}$ \\
SI0P5 & 19.67 & $4360 \mathrm{~b}$ \\
SI200P0 & 24.33 & $5070 \mathrm{~b}$ \\
SI100P5 & 23.67 & $4810 \mathrm{ab}$ \\
SI0P0 & $16.00^{* *}$ & $3031 \mathrm{~b}$ \\
\hline BNJ 5\% & - & \multicolumn{2}{c}{2897} \\
\hline
\end{tabular}

Data Tabel 3 menunjukkan bahwa pemupukan silikat dan pupuk kandang tidak berpengaruh secara nyata terhadap berat 1000 biji. Berat 1000 biji sorgum pada perlakuan kontrol adalah $16 \mathrm{~g}$ sedangkan berat tertinggi 1000 biji sorgum pada perlakuan pemupukan Si $200 \mathrm{~kg} / \mathrm{ha}$ dan 5ton/ha pupuk kandang sebesar $26 \mathrm{~g}$. Hasil penelitian ini menunjukkan bahwa perlakuan pemupukan silikat dan pupuk kandang masih belum mampu meningkatkan kualitas biji sorgum yang terukur dalam berat kering 1000 biji sorgum. Selanjutnya pemupukan silikat dan pupuk kandang mampu meningkatkan hasil sorgum. Hasil sorgum tertinggi diperoleh pada perlakuan pemupukan silikat $200 \mathrm{~kg} / \mathrm{ha}$ dan pupuk kandang 5 ton/ha dengan hasil sorgum sebesar 6056,47 kg/ha dibandingkan dengan perlakuan kontrol(tanpa pupuk silikat dan tanpa pupuk kandang) sebesar 3031,49 kg/ha.

Pemupukan silikat $200 \mathrm{~kg} / \mathrm{ha}$ dan pupuk kandang 5 ton/ha mampu meningkatkan hasil sorgum mencapai hampir $100 \%$. Data dari hasil penelitian ini menunjukkan bahwa pengaruh pupuk silikat dan pupuk kandang baru terlihat berpengaruh pada saat pertumbuhan generatif yaitu pada fase pengisian biji. Peningkatan kadar silikat di dalam tanah diperlukan dalam pengisian biji. Selanjutnya boleh jadi mineralisasi pupuk kadang menjadiunsur hara yang diperlukan oleh tanaman sorgum baru mencapai level yang mampu mempengaruhi hasil tanaman pada saat mulai mencapai pertumbuhan generatif. Pemupukan silikat sangat diperlukan untuk mennghasilkan biji pada fase generatif. Hal ini sependapat dengan Amujoyegbe (2007), penggunaan pupuk anorganik dan pupuk organik dapat meningkatkan hasil karena dapat meningkatkan mineral di dalam tanah dan dapat mentranlokasikan mineral ke tanaman sehingga meningkatkan nutrisi yang terdapat pada tanaman.

Nutrisi tanaman yang tersedia dalam aras yang mencukupi dapat digunakan untuk pertumbuhan tanaman generatif dalam proses fisiologis tanaman yang dapat meningkatkan hasil produksi biji. Menurut Sumarno (2013), pada proses generatif dimulai dari pembentukan bunga hingga pemasakan biji sorgum, ketersediaan unsur hara didalam tanah yang optimal dapat meningkatkan hasil produksi. Lebih jauh, Subdibyo (2008) mengungkapkan bahwa pemberian Silikat pada tanah entisol dapat meningkatkan ketersediaan posfor $(\mathrm{P})$ alam tanah, boleh jadi silikat mengubah $\mathrm{P}$ yang tidak terlarut menjadi $\mathrm{P}$ terlarut dan tersedia bagi tanaman.

Meningkatnya kadar fosfor di dalam tanah yang boleh jadi menjadi penyebab meningkatnya hasil panen biji sorgum karena peningatan kadar fosfor yang ada di dalam tanah. Hal ini sejalan dengan data bahwa kadar $\mathrm{P}$ tanah yang digunakan untuk penelitian adalah berstatus sangat rendah $(5,12 \mathrm{mg} / 100 \mathrm{~g}$ tanah).

\section{Berat berangkasan basah dan karing pada tanaman sorgum (kg/ha)}

Tabel 4. Rerata Berat Berangkasan Basah dan Kering (kg/ha)

\begin{tabular}{lll}
\hline Perlakuan & $\begin{array}{l}\text { Berat Berangkasan } \\
\text { Basah (gram) }\end{array}$ & $\begin{array}{l}\text { Berat Berangkasan } \\
\text { Kering (gram) }\end{array}$ \\
\hline SI100P0 & $13616.77 *$ & $5711.11^{*}$ \\
SI200P5 & 10840.53 & 4624.41 \\
SI0P10 & 10443.93 & 4358.69 \\
SI200P10 & 12030.35 & 5147.93 \\
SI100P10 & 12955.76 & 4981.36 \\
SI0P5 & 12426.95 & 4969.46 \\
SI200P0 & 12294.75 & 4783.06 \\
SI100P5 & 12823.56 & 4838.58 \\
SI0P0 & $7138.89 * *$ & $3462.36 * *$ \\
\hline BNJ 5\% & \multicolumn{2}{c}{-} \\
\hline Keterangan: Ni1ai Rata-rata tertingi
\end{tabular}

Keterangan: *Nilai Rata-rata tertinggi **Nilai rata-rata terendah

Data Tabel 4 menunjukkan bahwa pemberian pupuk silikat dan pupuk kandang tidak berpengaruh nyata terhadap berat berangkasan basah dan kering ( $\mathrm{kg} / \mathrm{ha})$. Berat berangkasan basah dan kering pada perlakuan kontrol sebesar 7138,89 kg/ha dan 3462,36 $\mathrm{kg} / \mathrm{ha}$ dan perlakuan tertinggi pada pemberian pupuk silikat $100 \mathrm{~kg} / \mathrm{ha}$ dan tanpa pemberian pupuk kandang sebesar 13616,77 kg/ha dan 5711,11 kg/ha. Pemberian pupuk silikat $100 \mathrm{~kg} / \mathrm{ha}$ dan tanpa pupuk kandang dapat meningkatkan hasil berat berangkasan basah dan kering hampir mencapai 50\% dibandingkan dengan kontrol (Tanpa pupuk silikat dan pupuk kandang). Data dari hasil penelitian ini menunjukkan bahwa tanaman dapat merespon pupuk silikat pada fase 
generatif yang dapat meningkatkan berat berangkasan tanaman sorgum.

Penambahan pupuk silikat dapat mengurangi terjadinya cekaman air pada kondisi lahan yang kering hal ini disebabkan karena penurunan kecepatan transpirasi melalui sel epidermal daun sehingga mengurangi proses transpirasi. Semakin tinggi proses laju fotosintesis maka semakin banyak pula net fotosintat yang diperoleh. Berat berangkasan kering pada tanaman tergantung pada net fotositat yang dihasilkan dari laju fotosintesis (Yoshida, 1982). Hal ini sejalan dengan hasil penelitian Husain dan Suriadikarta (2011) yang menunjukkan bahwa, penambahan silikat yang cukup dapat mengurangi tanaman padi layu pada kondisi kekeringan karena penurunan permebilitas uap air dari dinding sel epidermal daun sehingga tidak menghambat proses laju fotosintesis dan candangan karbohidrat yang tersimpan pada tanaman tidak berkurang sehingga berat kering pada tanaman padi tidak rendah.

\section{Kadar Brix (Kadar Gula) pada batang sorgum}

Pengaruh pupuk silikat (Si) dan pupuk kandang berbeda nyata terhadap nilai kadar brix pada umur 77 HST, 91 HST, 107 HST, 128 HST dan pada umur 101 HST tidak berbeda nyata di lihat pada Tabel 5.

Tabel 5. Rerata Kadar Brix Pada Batang Sorgum

\begin{tabular}{llllll}
\hline \multirow{2}{*}{ Perlakuan } & \multicolumn{4}{l}{ Kadar Brix (Kadar Gula) pada Berbagai Umur HST } & \\
& $77 \mathrm{HST}$ & $91 \mathrm{HST}$ & $101 \mathrm{HST}$ & $107 \mathrm{HST}$ & $128 \mathrm{HST}$ \\
\hline SI100P0 & $11,00 \mathrm{a}$ & $15,22 \mathrm{ab}$ & 17,89 & $14,78 \mathrm{a}$ & $11,61 \mathrm{ab}$ \\
SI200P5 & $11,44 \mathrm{a}$ & $14,44 \mathrm{ab}$ & 16,11 & $17,56 \mathrm{a}$ & $12,78 \mathrm{ab}$ \\
SI0P10 & $13,00 \mathrm{a}$ & $16,89 \mathrm{a}$ & 16,89 & $14,89 \mathrm{a}$ & $13,44 \mathrm{ab}$ \\
SI200P10 & $11,00 \mathrm{a}$ & $14,67 \mathrm{ab}$ & 17,33 & $15,11 \mathrm{~b}$ & $12,22 \mathrm{ab}$ \\
SI100P10 & $13,44 \mathrm{a}$ & $14,56 \mathrm{ab}$ & 16,89 & $15,22 \mathrm{a}$ & $12,44 \mathrm{ab}$ \\
SI0P5 & $11,22 \mathrm{a}$ & $14,33 \mathrm{ab}$ & 16,67 & $16,22 \mathrm{a}$ & $13,78 \mathrm{a}$ \\
SI200P0 & $8,56 \mathrm{~b}$ & $16,22 \mathrm{ab}$ & 18,00 & $17,00 \mathrm{a}$ & $12,78 \mathrm{ab}$ \\
SI100P5 & $8,44 \mathrm{~b}$ & $13,44 \mathrm{~b}$ & 16,33 & $16,00 \mathrm{a}$ & $12,67 \mathrm{ab}$ \\
SI0P0 & $7,89 \mathrm{~b}$ & $11,44 \mathrm{~b}$ & 17,44 & $9,33 \mathrm{~b}$ & $7,67 \mathrm{~b}$ \\
\hline BNJ 5\% & 2,86 & 3,77 & NS & 3,37 & 3,67 \\
\hline
\end{tabular}

Keterangan: Angka yang diikuti dengan huruf yang sama pada kolom yang sama menunjukkan tidak berbeda nyata menurut uji BNJ pada taraf 5\%

Data Tabel 5. Pengaruh pemberian pupuk silikat dan pupuk kandang terhadap kadar brix tanaman sorgum tidak berpengaruh nyata pada umur 101 HST. Hal ini disebabkan karena pada umur 101 HST kadar brix sudah mencapai tingkat maksimum pada semua perlakuan inilah saat terjadinya kadar brix maksimum. Sejalan dengan hasil penelitian Oyier et al (2017), yang menunjukkan bahwa pada umur tanaman 101117 HST dapat menghasilkan nilai kadar brix yang tinggi. Selanjutnya pemberian pupuk silikat dan pupuk kandang berpengaruh nyata terhadap kadar brix pada umur 77 HST, 91 HST, 107 HST, dan 128 HST. Pemberian pupuk silikat $200 \mathrm{~kg} / \mathrm{ha}$ dan pupuk kandang 10 ton/ha menghasilkan nilai kadar brix tertinggi dibanding dengan kontrol (tanpa pupuk silikat dan pupuk kandang). Data hasil penelitian ini menunjukkan bahwa Silikat dapat menekan aktivitas enzim invertase dalam batang tanaman, sehingga produksi sukrosa meningkat, energi yang tinggi dibutuhkan untuk pertumbuhan tanaman tebu dan produksi gula yang optimal. Menurut Liang et al. (2015) penambahan pupuk silikat pada tanaman tebu dapat meningkatkan hasil produksi dan produksi gula pada tebu. Menurut Makarim, (2007), Silikat (Si) diserap oleh tanaman dalam bentuk asam monosilikat atau (monosilicic acid) atau $\mathrm{Si}(\mathrm{OH}) 4$.Peran $\mathrm{Si}$ pada tanaman tebu diketahui adanya komplek enzim-Si yang berperan sebagai protektor dan regulator dalam proses fotosintesis dan kaegiatan enzim. Menurut Yukamgo dan Yuwono (2014), Pemberian pupuk silikat yang cukup pada tanaman serealia mampu memperoleh hasil yang baik, karena penambahan pupuk silikat dapat meningkatkan kekuatan dan ketahanan sel. Hasil produksi akan menurun jika kadar brix pada tanaman sorgum menghasilkan nilai yang tinggi, peningkatan kadar brix yang terdapat pada sorgum menunjukkan bahwa ketika biji mulai matang karna terdapat lebih banyak karbohidrat yang tersimpan di batang tanaman sorgum (Oyier et al, 2017)

Pupuk kandang dapat menambah ketersediaan unsur hara dalam tanah yang dapat diserap oleh tanaman (Sutejdo, 2007). Bahan organik tersebut akan mempengaruhi dan memperbaiki sifat fisik tanah seperti, meningkatkan kemampuan memegang air, aerasi, resistensi terhadap erosi air, penetrasi akar dan menstabilkan suhu tanah, memperbaiki sifat kimia tanah seperti, meningkatkan ketersediaan mineral, stabilitas $\mathrm{pH}$, nutrient reservoir, dan meningkatkan sifat biologi tanah, seperti merangsang aktifitas mikrobia yang berguna, mereduksi parasit (Soepardi, 1979). Pupuk kandang dapat menjadi cadangan unsur hara pada tanah yang dibutuhkan oleh tanaman menjadi tersedia seperti $\mathrm{N}, \mathrm{P}, \mathrm{K}, \mathrm{Ca}, \mathrm{Mg}$, dan $\mathrm{S}$, selain 
itu, kelebihan pupuk kandang, dapat memperbaiki struktur tanah dan menghasilkan kadar lengas tanah, menambah unsur hara, menambah kandungan humus atau bahan organik dan memperbaiki kehidupan jasad renik yang hidup dalam tanah (Samadi dan Cahyono,2005). Penggunaan pupuk anorganik dan pupuk organik dapat meningkatkan hasil karena dapat meningkatkan mineral dalam tanah dan dapat mentranlokasikan mineral ke tanaman sehingga meningkatkan nutrisi yang terdapat pada tanaman (Amujoyegbe et al, 2007).

Pada umur 101 HST nilai kadar brix memiliki nilai yang maksimum berbeda nyata dengan umur 77 HST, 91 HST, 107 HST dan 128 HST.

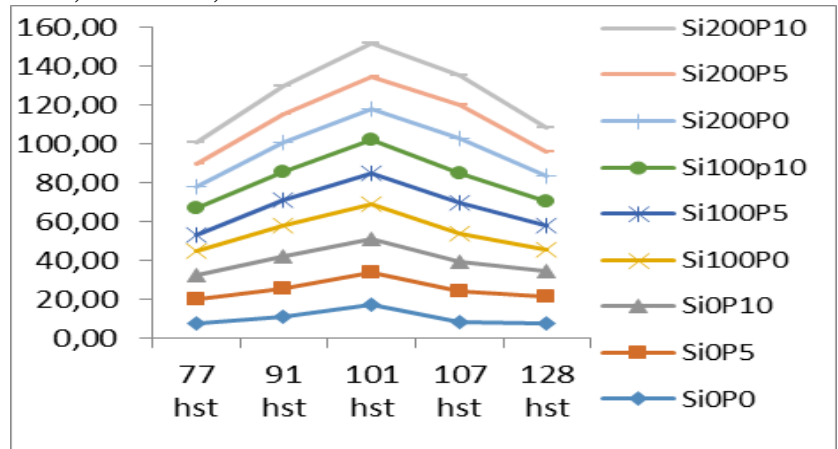

Gambar 1. nilai rerata kadar brix pada berbagai umur (HST)

Dilihat dari Gambar 1nilai kadar brix tertinggi pada perlakuan pupuk silikat $200 \mathrm{~kg} / \mathrm{ha}$ dan pupuk kandang 10 ton/ha, dan pada umur 101 HST nilai kadar brix sudah mencapai titik maksimum. Pada umur 101 HST menunjukan beda nyata terhadap umur 77 HST, 91 HST, 107 HST, dan 128 HST dan sudah diuji lanjut dengan BNT 5\%.

Pada umur 101 HST kadar brix sudah mencapai titik maksimum pada tanaman. Kadar brix batang adalah zat padat kering (Sukrosa, glukosa, fruktosa, dan lain-lain) terlarut dalam larutan yang dihitung sebagai sukrosa. Semakin tinggi kadar brix maka semakin manis larutan tersebut (Toure et al, 2004). Semakin mendekati umur panen kadar brix meningkat dan mengalami penurunan kadar brix setelah melewati masa umur panen akibat aktivitas enzim envertase pada tanaman. Hal yang sama diungkapkan oleh Oyier et al (2017) bahwa peningkatan kadar brix pada sorgum menunjukan bahwa ketika biji pada sorgum matang karena terdapat lebih banyak karbohidrat yang tersimpan pada bagian batang.

\section{Kesimpulan}

Berdasarkan hasil analisis dan pembahasan yang telah dilakukan, maka dapat diambil kesimpulan bahwa pemberian pupuk silikat dan pupuk kandang tidak berpengaruh secara nyata terhadap tinggi tanaman, berat basah dan berat kering jaringan tanaman dan berat 1000 butir. Pemberian pupuk silikat dan pupuk kandang mampu meningkatkan kadar brik juice batang sorgum dari umur 77 HST sampai 107 HST secara nyata dan mampu meningkatkan hasil sorgum secara nyata. Hasil sorgum tertinggi diperoleh pada perlakuan pemupukan silikat $200 \mathrm{~kg} / \mathrm{ha}$ dan pupuk kandang 5 ton/ha dengan hasil sorgum sebesar $6056 \mathrm{~kg} / \mathrm{ha}$

\section{Ucapan Terimakasih}

Terima kasih disampaikan pada Pusat Penelitian dan Pengembangan Teknologi Ketenagalistrikan, Energi Baru dan Terbarukan, dan Konservasi Energi (P3TKEBTKE), Balitbang Kementrian ESDM Jakarta yang telah membiayai penelitian ini.

\section{Daftar Pustaka}

Adisarwanto, T., (2002). Meningkatkan Produksi Kacang Tanah di Lahan Sawah dan Lahan Kering. Penebar Swadaya. Jakarta. 50-60 hal.

Afriani. P. (2018). Pengaruh pemberian pupuk silikat cair terhadap produksi tanaman sawi dan selada. Skripsi Fakultas Pertanian Universitas Mataram.

Amujoyegbe, B. J., T. Opabode, M A. Olayinka. (2007). Effect of Organic and Inorganic Vertilizer on Yield and Chlorophyll Content of Myz (Zea mays L) and Sorghum bicolor L Moench). Africall Journal of Biotechnologi 6 (16:1869-1873).

Diansyah. (2017). Respon Pertumbuhan dan Bobot Malai Kering Panen Tanaman Sorgum (Sorghum bicolor (L) Moench) Akibat Pemberian Bahan Pembenah Tanah dan Penerapan Sistem Irigasi di Lahan Kering Lombok Utara. Tesis Program Magister Pengolahan Sumber Daya Lahan Kering. Universitas Mataram.

Galuh. (2012). Pertumbuhan dan Hasil Sorgum Manis (Sorghum bicolor (L.) Moench) Tanam Baru dan Ratoon Pada Jarak Tanam Berbeda. Fakultas Pertanian Universitas Gajah Mada: Yogyakarta.

Hakim N, Nyakpa Y.M., Lubis M.A., Nugroho G.S., Saul RM., Diha AM., Hong B.G., dan Bailey H.H. (1986). Dasar Dasar Ilmu Tanah. Universitas Lampung.

Hirjani dan Suwardji (2017). Pengaruh pupuk NPK dan Pupuk Kandang terhadap Pertumbuhan, Hasil, Serapan N dan Efisiensi Penggunaan Air Tanaman Sorgum di Lahan Kering Lombok Utara. Laporan Penelitian Kerjasama UNRAM dan LITBANG Kementrian ESDM Jakarta.

Husain dan Suriadikarta D. A. (2011). Pengaruh Silikat terhadap Pertumbuhan dan Hasil Tanaman Padi Sawah di Tanah Ultisol. Balai Penelitian Tanah. Balitbang Pertanian Bogor. 
Liang, Y., M. Nikolic, R. Belanger, H. Gong, dan A.Song (2015). Silicon in Agriculture: From Theory to Practice. Springer London.

Ma'shum, M., (2013). Memahami Masalah dan Ikhtiar Penanggulangan Pembatas Produktivitas Lahan Kering. Buku Sang Profesor. Fakultas Pertanian Universitas Mataram

Makarim A. (2007). Silicon: Hara Penting Pada Sistem Produksi Padi. Iptek tanaman pangan. 2 (2).

Mayadewi. (2007). Pengaruh Jenis Pupuk Kandang dan Jarak Tanam terhadap Pertumbuhan Gulma Hasil Jagung Manis. Jurnal Agritrop, 26 (4): 153-159 ISN: 02158620.

Motagally. F.A. (2010). Evaluation of Water Use Efficiency under Different Water Regimes in Grain Sorghum (Sorghum bicolor (L.) Monech). World Journal of Agricultural Sciences 6(5): 499-505.

Muui C.W., R.M. Muasya, dan DT. Kirubi. (2013). Base Line Survey on Factors Affecting Sorghum Production and Use in Eastern Kenya. African Journal of Food Agriculture Nutrition and Development. 13 (1):7339-7358.

Nasahi, Ceppy, M.S. (2010). Peran Mikrobia dalam Pertanian Organik.Bandung: Jurusan Hama dan Penyakit Tumbuhan Fakultas Pertanian Universitas Padjadjaran.

Noor, A. dan RD. Ningsih. (1998). Upaya Meningkatkan Kesuburan dan Produktivitas Tanah di Lahan Kering. Proseding Lokakarya Strategi Pembangunan Pertanian Wilayah Kalimantan. Instalasi Penelitian dan Pengkajian Pertanian Banjarbaru.

Oyier, M.O., J.O. Owuoche, M.E. Oyoo. (2017). Effect of Harvesting Stage on Sweet Sorghum Genotype s in Western Kenya.The Scientific Journal. 4(2017): 467476.

Puteri, E, Yayuk Nurmiaty dan Agustiansyah. (2014). Pengaruh Aplikasi Fosfor dan Silika Terhadap Pertumbuhan dan Hasil Tanaman Kedelai (Glycine max (L.) Merrill.). Jurnal Agrotek Tropika. Vol 2, No. 2: 241-245

Ratnavanthi, C.V., Suresh, B.S., Vinjay Kumar, M. Pallavi, V.V. Komala dan N. Seetharama. (2010). Study on genotipe variation for ethanol production from sweet sorghum juice. Journal Agritrop, 26(4): 153-159.

Samadi B dan B. Cahyono. (2005). Intensifikasi Budidaya Bawang Merah Kanisius Yogyakarta.74 Hal.

Soepardi. (1979). Sifat dan Ciri Tanah. Departemen Ilmu Tanah Fakultas Pertanian. IPB: Bogor.

Sumarno, (2007). Kedelai: Teknik Produksi dan Pengembangan. Badan Penelitian dan Pengembangan Tanaman Pangan. Bogor. $512 \mathrm{hlm}$

Sutedjo. M.M. (2002). Pupuk dan Pemupukan. Rineka Cipta Jakarta.

Sutrisna, N. (2012). Sorgum dalam Penganekaragaman Penyediaan Pangan. Di dalam Suarni. 2004.
Pemanfaatan Tepung Sorgum untuk Produk Olahan. Jurnal Litbang Pertanian. 23(4):146.

Suwardji, Sri Tejowulan, A. Rahman dan Badrul Munir (2003). Rencana Strategis Pengembangan Lahan Kering Provinsi NTB. Bappeda NTB Press.

Suwardji, Suardiari G dan Hippi A., (2007). Meningkatkan Efisiensi air irigasi dari "sumber air tanah dalahm" pada Lahan Kering Pasiran Lombok Utara menggunakan teknologi irigasi sprinkler big gun. Prosiding Kongres Nasional HITI IX, 5-7 Desember 2007, Yogyakarta.

Suwardji dan Setio Hadi Waluyo. (2016). Laporan Penelitian Mencari Skenario untuk Meningkatkan Produktivitas Sorgum di Lahan Kering. Kerjasama BATAN Jakarta dan Universitas Matqram.

Toure, A., F.W. Rattunde, E. Weltzien. (2004). Guinea sorghum Hybrids: Bringing the Benefits of Hybrid Technology to A Staple Crop of Sub Saharan Africa. IER-ICRISAT.

Yoshida, S. (1981). Principles and Practice of Rice Production. The IRRI, Philippines.

Yukamgo, E. Dan Yuwono N.W. (2007). Peran Silikon Sebagai Unsur Bermanfaat pada Tanaman Tebu. Jurnal Ilmu Tanah dan Lingkungan Universitas Gajah Mada, 23(4): 103-116. 